\title{
РЕАЛІЗАЦІЯ ТЕХНОЛОГІї ТВОРЧОГО САМОРОЗВИТКУ СТУДЕНТІВ
}

У статті розглядаються теоретичні засади технологї творчого саморозвитку студентів та результати ії експериментальної апробації у навчальному процесі вищої школи.

Ключові слова: евристичне навчання, творчий саморозвиток, технологія творчого саморозвитку.

В статье рассматриваются теоретические основы технологии творческого саморазвития студентов и результать ее экспериментальной апробации в учебном процессе высшей школь.

Ключевые слова: эвристическое обучение, творческое саморазвитие, технология творческого саморазвития.

This article discusses the theoretical fundamentals of creative self-development of students and the results of its experimental testing in the educational process of higher education.

Key words: heuristic learning, creative self-development, technology of creative self-development.

Суттєві соціально-економічні та політичні перетворення, що відбуваються в Україні, зумовлюють необхідність підготовки фахівців, які спроможні на високому творчому рівні розв'язувати завдання розбудови держави. Сучасна парадигма національної освіти головною освітньою метою визначає створення умов для особистісного розвитку та самореалізації кожного громадянина. Питання творчого саморозвитку студентів стало настільки актуальним, що по праву вважається одним із основних складових підготовки спеціаліста.

Розв'язання зазначеної проблеми потребує впровадження в навчальний процес інноваційної технології, що грунтувалося б на внутрішньому стимулюванні активності студентів, їх особистому варіативному цілепокладанні, самостійному визначенні завдань і створенні власного освітнього продукту. Ефективним засобом стимулювання творчого саморозвитку майбутніх педагогів сучасна психолого-педагогічна наука називає евристичну діяльність та ії дидактичний складник - евристичне навчання.

Дослідженням сучасного стану проблеми саморозвитку особистості в навчальному процесі (кін. XX - поч. XXI ст.) присвятили свої роботи В. Андреєв, В. Алфімов, Є. Бондаревська, К. Вазіна, T. Войтенко, Б. Вульфов, О. Газман, В. Горшкова, Д. Григор'єв, Т. Давиденко, О. Іванов, С. Карпенчук, Л. Кулікова, С. Кульневич, В. Ланцберг, О. Мельник, А. Окунєв, Ю. Орлов, Г. Полякова, А. Сущенко, В. Сластьонін, В. Хайруліна, Т. Шамова; найбільший акцент на проблемі творчого саморозвитку особистості зробили у своїх дослідженнях М. Костенко, О. Слободян, Р. Цокур, Н. Чинкіна та інші.

Питання евристичного навчання, евристичної діяльності розглянуто в працях таких учених, як Т. Дмитренко, Ю. Кулюткін, В. Лозова, О. Лук, О. Матюшкін, В. Моляко, В. Пушкін, К. Пчьоліна, В. Соколов, Л. Спірін, Н. Тализіна, Д. Троїцький, А. Хуторський та інші.

У фаховій літературі недостатньо висвітлені дидактичні аспекти творчого саморозвитку студентів, зокрема, потенційні можливості евристичного навчання.

Метою статті є аналіз результатів експериментальної роботи з реалізації технології творчого саморозвитку студентів.

Аналіз наукової літератури 3 питань творчості (Г. Альтшулер, Д. Богоявленська, А. Маслоу, К. Роджерс, Е. Фромм та ін.), творчої активності та діяльності (Ш. Амонашвілі, Ю. Бабанський, Л. Виготський， В. Давидов， І. Лернер， В. Паламарчук， С. Рубінштейн， В. Сухомлинський та ін.), евристичного навчання (В. Андреєв, В. Воронін, П. Каптерев, М. Лазарев, А. Хуторськой та ін.) дозволяє виокремити евристичне навчання як засіб творчого саморозвитку майбутніх педагогів. Науковці розглядають евристичне навчання як основний дидактичний складник евристичної діяльності - тип навчання студентів, у результаті якого здійснюється пошук та створення нового в їх знаннях, уміннях, способах діяльності, особистісних якостях, матеріалізованих продуктах навчання [4; 5]. Основою та першоджерелом евристичного навчання є евристика - засноване на досвіді правило, стратегія, прийом чи інший засіб, що суттєво обмежує пошук розв'язування важкої задачі [3].

Зміст евристичного навчання передбачає цілепокладання, побудову власної освітньої траєкторії, зіставлення особистих продуктів діяльності 3 культурно-історичними аналогами. У результаті евристичне навчання стає механізмом пізнавального саморуху, саморозвитку особистості.

Проблема творчого саморозвитку здавна була в центрі уваги філософів, педагогів, психологів, громадських діячів. Ідея творчого саморозвитку не нова для нашого суспільства, проте вона не може вважатися вирішеною, оскільки й дотепер дискусійними $є$ питання щодо конкретних цілей, змісту, методів, форм навчального процесу, спрямованого на його активізацію. Тому сучасні вимоги щодо підготовки фахівців зумовлюють інноваційні технологічні підходи до організації навчального процесу. 
Саморозвиток розуміється як усвідомлений і керований особистістю процес, у результаті якого відбувається удосконалення фізичних, розумових і моральних потенцій людини, розгортання іiі індивідуальності. Він сприяє самовдосконаленню та самореалізації особистості. Зовнішніми факторами саморозвитку є впливи середовища та цілеспрямований навчальний процес. Внутрішніми - потреби, мотиви, інтереси та установки особистості [1, с. 33].

У контексті нашого дослідження поділяємо думку О. Слободян, яка розглядає творчий саморозвиток особистості студента як «умотивовану, свідому, відрефлексовану на основі самопізнання, самовизначення, самоконтролю, самоосвіти діяльність, спрямовану на самовдосконалення природних та духовних якостей, на розвиток творчого потенціалу, діалогового дивергентного мислення, на моделювання власного способу життя в соціокультурному контексті, на самореалізацію творчих здібностей у процесі життєтворення та професійно-педагогічного становлення» [2].

У дослідженні за базове обрано положення про те, що творчий саморозвиток - це вмотивована, усвідомлена, рефлексивна творча діяльність, спрямована на забезпечення успішної професійної та життєвої самореалізації. Його основними сферами виступають майбутня професійна діяльність та особисте життя. Такий комплексний феномен розглянуто з позицій двох підходів - процесуального та особистісного.

На основі аналізу сутності феномену творчого саморозвитку та його функцій (розвитку мотивів творчої діяльності, загального розумового розвитку, розвитку індивідуально-творчих якостей, проектування діяльності майбутнього педагога, саморегуляції особистості) ми виділяємо структурні компоненти творчого саморозвитку майбутніх педагогів та їх критерії:

- мотиваційний компонент - провідний критерій - мотиваційно-розвивальний;

- когнітивний компонент - провідний критерій - пізнавально-творчий;

- творчий компонент - провідний критерій - креативно-діяльнісний;

- оргдіяльнісний компонент - провідний критерій - організаційно-діяльнісний;

- $\quad$ рефлексивний компонент - провідний критерій - аналітико-результативний.

На основі визначених концептуальних положень щодо творчого саморозвитку нами теоретично обгрунтовано та експериментально перевірено технологію його реалізації, модель якої відображає взаємозв'язок мотивів, мети, змістовно-процесуальної складової творчого саморозвитку, його компонентів, рівнів інтенсивності, критеріїв та показників, функцій та принципів, дидактичних умов та етапів реалізації технології.

Реалізація технології творчого саморозвитку майбутніх педагогів здійснювалася за допомогою програм евристичного забезпечення вивчення навчальних дисциплін. Методичне забезпечення включало адекватні евристичні форми (лекція-діалог, лекція 3 введення культурно-історичних аналогів, лекція теоретичного конструювання, пошуковий семінар, семінар генерації ідей, метод проектів, творчі тижні тощо), методи (метод конструювання понять, метод цілепокладання, метод евристичних запитань, метод «якщо б...» тощо), завдання (наукова проблема, «проживання» історії тощо).

Нами підтверджено логіку ефективної реалізації технології творчого саморозвитку за такими етапами:

- діагностичний (вивчення наявного рівня інтенсивності творчого саморозвитку майбутніх педагогів, визначення мети та завдань евристичного навчання, здійснення відбору форм, методів, прийомів і засобів евристичного навчання);

- мотиваційно-ціннісний (формування позитивної мотивації до творчого саморозвитку);

- самовизначення (складання програми творчого саморозвитку);

- самореалізації (впровадження евристичного навчання в широкому сенсі);

- $\quad$ рефлексивний (формування умінь та навичок самооцінки).

Узагальнені дані інтенсивності творчого саморозвитку майбутніх педагогів за результатами експериментальної роботи представлено в таблиці 1.

Одержані дані свідчать, що в результаті експериментальної роботи зросли рівні інтенсивності всіх компонентів творчого саморозвитку студентів як контрольних, так і експериментальних груп. У контрольних групах спостерігається незначне зростання показників (у межах 5\%). Уважаємо, що на такі зміни вплинула специфіка навчання майбутніх педагогів на факультетах мистецтв, де професійна діяльність тісно пов'язана із творчістю. Проте збільшення рівня мотивації ще не означає активної діяльності студентів щодо творчого саморозвитку. Найменше змінилися в контрольних групах показники когнітивного компонента; на нашу думку, на це вплинула традиційна система навчання, де провідною є репродуктивна діяльність студентів.

Узагальнені дані інтенсивності творчого саморозвитку майбутніх педагогів

\begin{tabular}{|c|c|c|c|c|}
\hline Рівні & \multicolumn{2}{|c|}{ Контрольні групи } & \multicolumn{2}{|c|}{$\begin{array}{c}\text { Експериментальні } \\
\text { групи }\end{array}$} \\
$\begin{array}{c}\text { творчичого } \\
\text { саморозвитку }\end{array}$ & До & Після & До & Після \\
\cline { 2 - 5 } & експерименту, & експерименту, & експерименту, & експериме \\
\hline
\end{tabular}




\begin{tabular}{|c|c|c|c|c|}
\hline & $\mathrm{y} \%$ & $\mathrm{y} \%$ & $\mathrm{y} \%$ & $\begin{array}{c}\text { нту, } \\
\mathrm{y} \%\end{array}$ \\
\hline Високий & 7,4 & 9,5 & 5,2 & 24,7 \\
\hline Достатній & 10,5 & 14,7 & 11,3 & 27,8 \\
\hline Середній & 32,6 & 36,8 & 34,0 & 30,9 \\
\hline Критичний & 30,5 & 24,2 & 36,1 & 13,4 \\
\hline Низький & 19,0 & 14,7 & 13,4 & 3,1 \\
\hline
\end{tabular}

Результати дослідної роботи щодо обгрунтування та перевірки ефективності технології творчого саморозвитку майбутніх педагогів підтверджують наше припущення про адекватність, необхідність та достатність таких дидактичних умов її реалізації:

- майстерність викладача в реалізації технології творчого саморозвитку (володіння теоретичними засадами та методикою активізації творчого саморозвитку студентів - знання та вміння педагога щодо організації евристичного навчання, створення ситуацій успіху в навчальній діяльності, надання методичної допомоги студентам у складанні індивідуальної програми творчого саморозвитку);

- створення творчого навчального середовища (обізнаність педагога у впровадженні та потенціал студента в опануванні евристичних форм, методів навчання для підвищення мотивації творчого саморозвитку, активізації пізнавальних процесів, створенні умов для творчої діяльності та розвитку творчого потенціалу, розвитку рефлексивних процесів);

- побудова індивідуальної програми творчого саморозвитку (фіксація студентами основних освітніх орієнтирів, вироблення системи особистісного ставлення до майбутньої професійної діяльності, виявлення пріоритетів, тактичних та стратегічних цілей, визначення форм і методів здійснення навчальної діяльності та життєдіяльності).

Аналіз матеріалів формувального експерименту дозволяе зробити висновок про дієвість авторської технології творчого саморозвитку майбутніх педагогів та ефективність ії реалізації. В експериментальних групах зростання всіх показників становить у середньому $15 \%$. В основному студенти вийшли на достатній і високий рівні інтенсивності компонентів творчого саморозвитку. Значно зменшився відсоток студентів, які знаходяться на низькому та критичному рівнях інтенсивності. Можемо стверджувати, що зросла не лише мотивація майбутніх педагогів до творчого саморозвитку, а й збільшилася кількість студентів, які виявили практичні вміння щодо самоорганізації, самовираження, узагальнення власного досвіду діяльності. Однак найменше зростання показників в експериментальних групах спостерігається за оргдіяльнісним компонентом. Труднощі виникали в деяких майбутніх педагогів із визначенням індивідуальної програми творчого саморозвитку та способів їі реалізації.

Розрахунки отриманих даних демонструють незначущість відмінностей у показниках контрольних груп до та після експерименту, а в експериментальних групах такі відмінності є суттєвими та статистично значущими. Достовірність одержаних нами результатів дослідження підтверджується методами математичної статистики (критерій Колмогорова-Смірнова -критерій $\lambda$ ).

Проведено дослідження не вичерпує всіх аспектів творчого саморозвитку майбутніх педагогів. Потребують подальшого вивчення проблеми творчого саморозвитку в інших видах навчальної діяльності, необхідно дослідити умови творчого саморозвитку школярів та методичні аспекти підготовки майбутніх педагогів до організації евристичного навчання.

\section{Література}

1. Дурманенко Є. А. Саморозвиток як творення особистості / Є. А. Дурманенко, Л. І. Корміна // Педагогічний пошук. - №3. - 1996. - С. 32 - 37. 2. Слободян О. П. Творчий саморозвиток особистості студентів педагогічного коледжу в процесі вивчення культурологічних дисциплін: автореф. дис. на здобуття ступеня канд. пед. наук : спец. 13.00 .04 / О. П. Слободян. - Луганськ, 2004. - 20 с. 3. Фридман Л. М. Психологопедагогические основы обучения математике в школе / Л. М. Фридман. - М. : Просвещение, 1983. - 160 с. 4. Хуторской А. В. Дидактическая эвристика. Теория и технология креативного обучения / А. В. Хуторской. М.: Изд-во МГУ, 2003. - 416 с. 5. Хуторской А. В. Современная дидактика: [учебник для вузов] / А. В. Хуторской. - СПб. : Питер, 2001. -544 с. 